\title{
ULTRA STRUCTURE OF BAUNG (Mystus nemurus) SPERMATOZOA
}

\author{
Muchlisin ZA \\ Department of Marine Sciences, Faculty of Sciences, Syiah Kuala University, \\ Banda Aceh 23111, NAD, Indonesia (Email: icin@eudoramail.com)
}

\begin{abstract}
ABSTRAK
Ultra struktur sperma ikan baung (Mystus nemurus) telah diamati dengan menggunakan transmisi dan imbas elektron mikroskop (TEM dan SEM). Hasil penelitian menunjukkan bahwa spermatozoa normal ikan baung terbagi atas tiga bagian yaitu; kepala, leher yang pendek, dan bagian ekor. Kepala sperma ikan baung berbentuk bulat yang diseliputi oleh membran sitoplasma, pada bagian leher terdapat mitokondria, sedangkan ekornya bersifat tunggal dan irisan melintangnya menunjukkan bahwa centriol mikrotubulusnya terbentuk atas " $9+2$ " axoneme.
\end{abstract}

Kata kunci: Mystus nemurus, spermatozoa, dan ultra structure

\section{INTRODUCTION}

Ultra structure spermatozoa studies have been intensively examined. Information on spermatozoa ultra structure is needed to understand spermatozoa biology, which is invaluable in the developing of spermatozoa cryopreservation methods (Lin et al., 1996) and further enhancing artificial induce breeding efforts. Mattei (1991) had been reviewed the sperm morphology of around 280 fishes using transmission and scanning electron microscope.

Baung is a popular catfish species currently being produced in both semi-intensive and intensive culture system in Malaysia, Thailand, and Indonesia. Reproductive biology of baung has reported by Khan et al. (1990). However, information of spermatozoa ultra structure of baung has not been described. The objective of the present study is to describe the sperm morphology of baung using transmission and scanning electron micrograph imaging.

\section{MATERIALS AND METHODS}

The study was carried out in Electron Microscope Laboratory of University Sciences Malaysia, Penang, Malaysia. Three male fishes weighing 589.7 to $654.4 \mathrm{~g}$ were anaesthetized and sacrificed by spinal transection. Testes were removed by dissection and perforated with a needle and gently squeezed into a glass tube which was placed on crushed ice, to obtain the sperms.

Sperm samples were fixed in $2.5 \%$ glutaraldehyde and kept for 48 hours. After 48 hours, sample was washed in cacodylate buffer for one hour, and then samples were post fixed for one hour in cacodylate buffer osmium tetroxide and rinsed several times in the buffer. For scanning electron microscopy (SEM), samples were attached to cover slip previously coated with $0.1 \%$ poly-L-lysine. After dehydration through an ascending series of acetone, the samples were critical point dried in critical point dryer, and coated with gold in sputter coated and viewed by using electron microscope (Leica Cambridge S-360, England). While, for transmission electron microscopy (TEM), the sperm pellet obtained by gentle centrifugation were dehydrated in acetone and embedded in resin. Thin sections of samples were picked up on copper grids, doubly stained with uranyl acetate and lead citrate and examined using electron microscope (Philips CM 12 TEM, Holland).

\section{RESULTS}

\section{Head and midpiece-sleeve}

Morphologically normal spermatozoa of baung consist of three distinct parts; head, midpieces-sleeve, and flagella (Figure 1a). The head of baung spermatozoa was rounded, sized $1.99 \mu \mathrm{m}$ in length and $1.73 \mu \mathrm{m}$ in width. They had a nucleus sized $1.44 \mu \mathrm{m}$ in length and $1.24 \mu \mathrm{m}$ in width, and its represent the chromatin. The head was completed with at least two-electrons nuclear lacuna sized $0.23 \mu \mathrm{m}$ which penetrate in the nucleus (Figure 1b).

The head was covered by cytoplasm membrane and the nucleus was bordered by nuclear envelope (ne), and cytoplasm channel (cl) was located between the flagellum (fl) and cytoplasm membrane (cm), while the mitochondrial (m) were located in the midpieces-sleeve. Transmission electron micrograph imaging showed that a single spherical mitochondrial was appeared in sized $0.36 \mu \mathrm{m}$ (Figure 1C). The midpieces-sleeve was sized around $1.49 \mu \mathrm{m}$ in length and $0.98 \mu \mathrm{m}$ in width. The nucleus was connected to a short midpiece-sleeve and the flagellum by a centriole complex, and the centriole complex was formed by distal centriole and proximal centriole, although its were not appeared in this observation. 


\section{Flagellum}

Baung spermatozoa were uniflagellate, the Flagellum sized around $4.10 \mu \mathrm{m}$ in length and $0.19 \mu \mathrm{m}$ in width. Cross section of the flagelllum showed the axoneme performed by nine peripheral doublets and single pair of central microtubulus (" $9+2$ " patterns) (Figure 1d). The flagellum membrane had one lateral projection (Figure 1e).

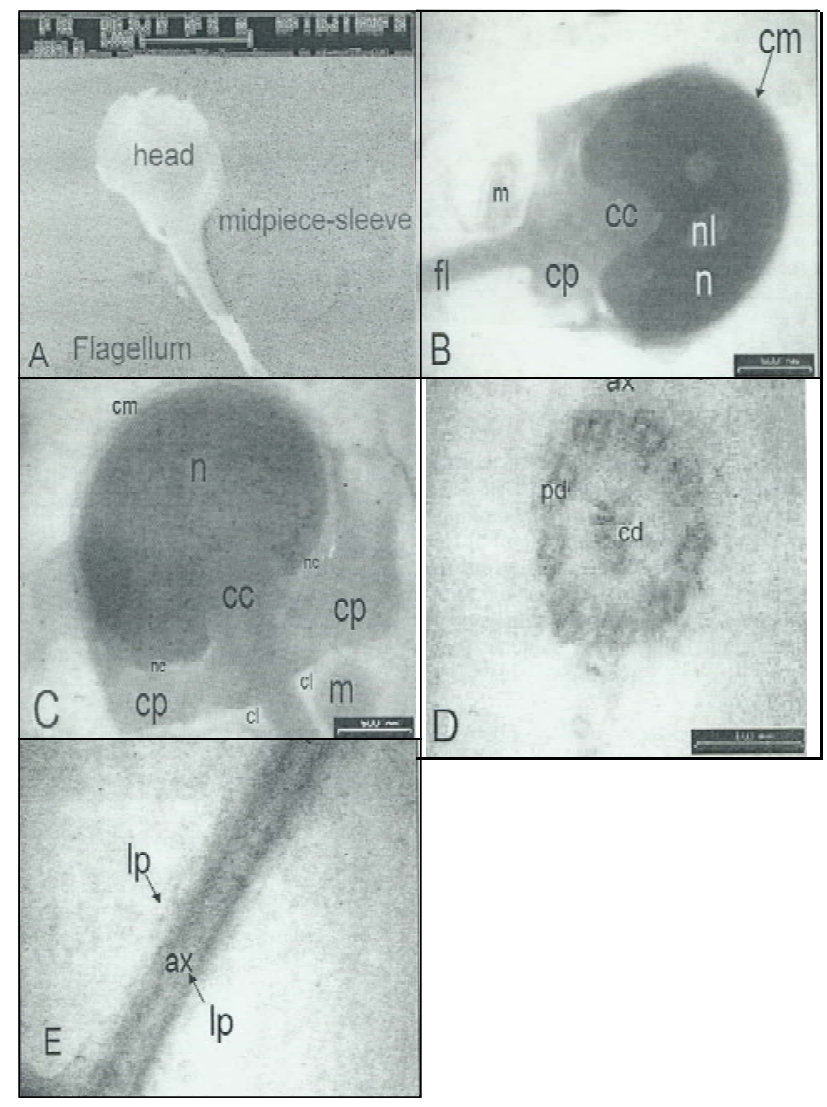

Figure 1a. SEM imaging of baung spermatozoa; B.TEM of baung sperm showed two nuclear lacunas at the nucleus; $C$. The head is covered by cytoplasmic membrane and one mitochondria was present at midpiece-sleeve; D. Cross section of flagellum show "9+2" patterns of axoneme; E. Longitudinal section of flagellum show lateral projections; F. Abnormal spermatozoa. Nucleus (n), flagellum (fl), nuclear lacuna (nl), cytoplasm membrane $(\mathrm{cm})$, nuclear envelope (ne), cytoplasm (cp), mithocondria $(\mathrm{m})$, axoneme (ax), cytoplasm canal (cl), centriole complex (cc), peripheral doublets $(p d)$, and central doublet (cd), lateral projection membrane (Ip)

\section{DISCUSSIONS}

In teleosts, the morphology of the spermatozoa is simple; the head is round or ovoid-shape, the middle piece is reduced to a mitochondrial ring and the flagellum present a typical " $9+2$ " structure (Suquet et al., 1993). The baung spermatozoa are a typical aquasperm with a spherical nucleus, short midpiece, and short cytoplasmic collar. Aquasperm is also found on other catfish such as African catfish, walking catfish, and Thai catfish. Another type is introsperm which found in internal fertilizes fish, for example in ocean pout (Yao et al., 1999).

Head spermatozoa of baung is rounded, and with no acrosome structure at the head. Acrosome structure has also absent in some species, for example in tilapia spermatozoa (Don and Avtalion, 1993), and turbot (Suquet et al., 1993).

The acrosome function is to breakdown the microphyle pore for penetration and fertilization of the egg. Acrosome is not necessary for fish spermatozoa due to the fish egg have a microphyle pore which is always opening to permit sperm passage to fertilize the egg (Amanze and Iyvegar, 1990). Once fertilization occurs, the micropyle pore is barred by filamentous network (Bern and Avtalion, 1990). The midpiece-sleeve of baung spermatozoa is short with single mitochondrial, a similar performance was found in turbot spermatozoa (Suquet et al., 1993). Whereas, a long midpiece-sleeve with at least nine mithocondrial was found in ocean pout (Yao et al., 1995).

There are two types of fish flagellum; uniflagellate and biflagellate. The flagellum of baung spermatozoa is uniflagellate with axoneme formed by nine peripheral doublets and single pair of central microtubules $(9+2$ structure), similar patterns were found in Thunnus thynnus and Euthynus alletteratus (Abascal et al., 2002). and Diplodus puntazzo (Taddei et al., 2001). Uniflagelate with " $9+1$ " patterns of axoneme was found in tilapia (Bern and Avtalion, 1990), and biflagellate with " $9+2$ " structure of axoneme is found in ocean pout (Yao, et al., 1995).

Numbers of flagellum are dependent on fish species; a single flagellum is found in fish such as Siluridae, Clariidae, Bagridae, Schibeidae, and Mochokidae. While, biflagellum is found in Ictaluridae, Pimelodidae, Ariidae, and Malapteruridae (Yao et al., 1999). In this study, we found some abnormal spermatozoa.

Our observation revealed the presence of abnormal cell in fresh sperm (Figure 1f), these abnormalities occurs naturally and we suspected that the abnormalities of sperm occur during spermatogenesis. However, most of the spermatozoa in the fresh milt have a normal structure.

Lastly we concluded that the baung spermatozoa could be divided into three distinct parts; head, midpieces-sleeve, and flagellum. The head of baung spermatozoa round forms, and covered by cytoplasmic membrane. The midpiece-sleeve is short with at least two mitochondria. The flagellum is uniflagellate, with nine peripheral doublets, and 
single pair of central microtubulus ("9+2" patterns) of axoneme. The type of spermatozoa is aquasperm.

\section{Acknowledgments}

We would like to express our thanks to $\mathrm{Mr}$. Patchamuthu Ramasamy, Mrs. Jamilah Afandi Mr. Johari, Mr. Jamil, Mr. Abubakar for their assistance during phases of the study.

\section{REFERENCES}

Abascal FJ, Medina A, Megina C, and Calzada A, 2002. Ultrastructure of Thunnus thynnus and Euthynnus alletteratus spermatozoa. Fish Biology 60: 147-153.

Amanze D and Iyvengar A, 1990. The micropyle: a sperm guidance system in teleost fertilization. Development, 109: 495-500.

Bern O and Avtalion RR, 1990. Some morphological aspect of fertilization in tilapias. Fish Biology 36: 375-381.

Don J and Avtalion RR, 1993. Ultraviolet irradiation of tilapia spermatozoa and the Hertwig effect: electron microscopic analysis. Fish Biology 42: 1-14.

Khan MS, Ambak MA, Ang KJ, and Mohsin AKM, 1990. Reproductive biology of a tropical catfish Mystus nemurus (C \& V) in Chenderoh resorvoir, Malaysia. Aquaculture Fisheries Management 2: 173-179.
Lin FL, Liu L, and Dabrowsky, 1996. Characteristics of muskelluge spermatozoa I: ultrastructure of spermatozoa and biochemical composition of semen. American Fisheries Society 125: 187-194.

Mattei X, 1991. Spermatozoon ultrastructure and its systematic implication in fishes. Canadian Journal of Zoology 69: 151-158.

Suquet M, Dorange G, Omnes MH, Normant Y, Le Roux A, and Fauvel C, 1993. Composition of the seminal fluid and ultrastructure of the spermatozoon of turbot (Scophthalmus maximus). Fish Biology 42: 509-516.

Taddei AR, Barbato F, Abelli L, Canese S, Moretti F, Rana KJ, Fausto AM, and Mazzini M, 2001. Is cryopreservation a homogenous process? Ultrastructure and motility of untreated, prefreezing, and postthawed spermatozoa of Diplodus puntazzo (Cetti). Cryobiology 42: 244-255.

Yao Z, Emerson CJ, and Crim LW, 1995. Ultrastructure of the spermatozoa and egg of the ocean pout (Macrozoarces americanus L) an internally fertilizing marine fish. Molecular Reproduction Development 42, 58-64.

Yao Z, Richardson GF, and Crim LW, 1999. A diluent for prolonged motility of ocean pout (Macrozoarces americanus L) sperm. Aquaculture 174: 183-193.

Reviewer: Drs. Win Darmanto. M.S., Ph.D. 